DOI https://doi.org/10.15589/znp2019.1(475).27

УДК 339.9.01

\title{
MECHANISMS OF FOREIGN INVESTMENT ATTRACTION: A REGIONAL DIMENSION
}

\section{МЕХАНІЗМИ ЗАЛУЧЕННЯ ІНОЗЕМНИХ ІНВЕСТИЦЙ: РЕГІОНАЛЬНИЙ ВИМІР}

\author{
Andrii V. Zavhorodnii \\ andrew-mdu@ukr.net \\ ORCID: 0000-0002-2598-2106
}

\author{
А. В. Завгородній \\ канд. фіз.-матем. наук, доцент
}

\begin{abstract}
Mykolayiv Interregional Institute for Human Development, Higher Educational Institution “Open International University for Human Development”, Mykolayiv

Миколаївський міжрегіональний інститут розвитку людини вищого навчального закладу «Відкритий міжнародний університет розвитку людини «Україна», м. Миколаїв
\end{abstract}

\begin{abstract}
Within the world economic system, various industrial, trade, credit, currency, scientific, technical and other relations are formed between national markets and their subjects. An important component of this relationship is international investment activities related to the export of capital. The main objective of the study is to investigate the mechanisms of attracting foreign direct investment to individual enterprises of the Black Sea region.

The methodological and theoretical basis of the work is the scientific provisions of fundamental and applied research in the field of economic theory, regional economy, agrarian economy, strategic management, planning and forecasting, systems theory, management of foreign economic activity, the work of domestic and foreign scientists in various fields of economic science fundamental theories of development of foreign economic activity at the regional level.

In order to achieve this goal, general and special research methods were used in the work: analysis and synthesis - to study the basic forms and mechanisms of attracting foreign direct investment; comparative-geographical method of systematization - the geographical structure is considered, which is formed under the influence of many factors, the main among which is the development of foreign economic relations with strategic partners; regional - the problems of attracting foreign direct investments to the enterprises of the Black Sea region are analyzed and proposals for the construction of an effective mechanism for attracting foreign direct investments are elaborated; statistical - provides statistics on the development of foreign direct investment in Ukraine.

The dynamics of foreign direct investment in the economy of Ukraine in 2010-2018, millions of dollars was determined. The dynamics of indicators of development of the object of research was clearly illustrated using graphical and cartographic methods. The information base of the research is laws of Ukraine, decrees of the President of Ukraine, resolutions of the Cabinet of Ministers of Ukraine, statistical materials of the State Committee of Statistics of Ukraine, main departments of statistics in the Autonomous Republic of Crimea, Mykolaiv, Odessa and Kherson regions, the Ministry of Economy of Ukraine, the Ministry of Agrarian Policy of Ukraine departments, research institutes, centers and foundations, scientific achievements of domestic and foreign authors, as well as materials of the department of development problems of the food complex consumer market and of the Council of Productive Forces of Ukraine. The practical significance of the obtained results is determined by the possibility of applying the formulated conclusions and recommendations for the development of the theory and methodology of the regional economy, in the preparation of programmatic and forecasting documents, determining the priorities of attracting foreign direct investment to the enterprises of the region in the latest conditions. The results of the analysis and identification of mechanisms for attracting foreign direct investment in the enterprises of the region make it possible to form regional strategies, sectorial and regional integrated programs of socio-economic development.

The conceptual bases of formation of mechanisms of attraction of direct foreign investments on the enterprises of the region are developed and the recommendations on formation of model of innovative development of the Black Sea region can be used as a basic project for creation of elements of infrastructure in other regions of Ukraine.
\end{abstract}

Key words: foreign direct investment; joint venture; free economic zone; concession; leasing.

Анотація. У межах світової економічної системи між національними ринками та їх суб’єктами формуються різні виробничі, торговельні, кредитні, валютні, науково-технічні й інші відносини. Важливим складником цих відносин є міжнародна інвестиційна діяльність, пов’язана з експортом капіталу. Основна мета дослідження - 
вивчити механізми залучення прямих іноземних інвестицій на окремі підприємства Чорноморського регіону. Методологічною й теоретичною основою роботи є наукові положення фундаментальних і прикладних досліджень у галузі економічної теорії, регіональної економіки, аграрної економіки, стратегічного управління, планування та прогнозування, теорії систем, управління зовнішньоекономічною діяльністю, роботи вітчизняних та іноземних учених у різних галузях економічної науки, фундаментальні теорії розвитку зовнішньоекономічної діяльності на регіональному рівні.

Для досягнення мети в роботі використано загальні та спеціальні методи дослідження: аналіз і синтез - для вивчення основних форм і механізмів залучення прямих іноземних інвестицій; порівняльно-географічний метод систематизації - розглядається географічна структура, яка формується під впливом багатьох факторів, основним серед яких є розвиток зовнішньоекономічних зв'язків зі стратегічними партнерами; регіональні аналізуються проблеми залучення прямих іноземних інвестицій на підприємства Чорноморського регіону та розробляються пропозиції щодо побудови ефективного механізму залучення прямих іноземних інвестицій; статистичний - надає статистику щодо розвитку прямих іноземних інвестицій в Україні.

Визначено динаміку прямих іноземних інвестицій в економіку України у 2010-2018 роках, мільйони доларів США. Динаміку показників розвитку об'єкта дослідження наочно проілюстровано графічними й картографічними методами. Інформаційною базою дослідження є закони України, укази Президента України, постанови Кабінету Міністрів України, статистичні матеріали Державного комітету статистики України, головних управлінь статистики в Автономній Республіці Крим, Миколаєві, Одеській і Херсонській областях, Міністерства економіки України, Міністерства аграрної політики України, відділів, науково-дослідних інститутів, центрів і фондів, наукові досягнення вітчизняних і зарубіжних авторів, а також матеріали відділу проблем розвитку продовольчого комплексного споживача ринку й Ради продуктивних сил України.

Практичне значення отриманих результатів визначається можливістю застосування сформульованих висновків і рекомендацій щодо розвитку теорії та методології регіональної економіки, під час підготовки програмних і прогнозних документів, визначення пріоритетів залучення прямих іноземних інвестицій до підприємства області в сучасних умовах. Результати аналізу та виявлення механізмів залучення прямих іноземних інвестицій на підприємства регіону дають можливість формувати регіональні стратегії, галузеві й регіональні інтегровані програми соціально-економічного розвитку.

Розроблені концептуальні засади формування механізмів залучення прямих іноземних інвестицій на підприємствах регіону та рекомендації щодо формування моделі інноваційного розвитку Чорноморського регіону можуть бути використані як базовий проект для створення елементів інфраструктури в інші регіони України.

Ключові слова: прямі іноземні інвестиції; спільне підприємство; вільна економічна зона; концесія; лізинг.

\section{ПОСТАНОВКА ЗАДАЧІ}

У межах світової економічної системи між національними ринками та їх суб'єктами складаються різноманітні виробничі, торговельні, кредитні, валютні, науково-технічні й інші відносини. Важливим складником цих відносин є міжнародна інвестиційна діяльність, пов'язана з вивезенням капіталу. Капітал є одним із факторів виробництва - peсурсом, який необхідно затратити для виготовлення будь-якої продукції. Капітал являє собою нагромаджений запас засобів у продуктивній, грошовій чи товарній формах, необхідний для створення матеріальних і нематеріальних благ і послуг. Міжнародний рух факторів виробництва (капіталу, ресурсів, робочої сили) регулюється тими ж законами, що й міжнародна торгівля товарами: фактори переміщуються в ті країни, де за них більше платять (вища процентна ставка, заробітна плата, ліцензійні платежі тощо).

Використання іноземних інвестицій для розвитку економіки окремих регіонів забезпечує більш швидке іiі входження до світової господарської системи. Стан вирішення проблеми інвестування є критерієм зрілості ринкових реформ, довіри світового співтовариства до політичного курсу держави.

\section{АНАЛІЗ ОСТАННІХ ДОСЛІДЖЕНЬ І ПУБЛІКАЦІЙ}

Теоретичні та практичні аспекти залучення коштів від іноземних інвесторів на вітчизняні підприємства розглядалися в наукових працях I.М. Бирки [1], Р.С. Зубкова [5], Р.М. Скупського [5], М.В. Ігнатенко [4] та ін. Натомість більшість дослідників не аналізують регіональні аспекти цієї проблеми.

\section{ВІДОКРЕМЛЕННЯ НЕ ВИРІШЕНИХ РАНІШЕ ЧАСТИН ЗАГАЛЬНОЇ ПРОБЛЕМИ}

Незважаючи на численні наукові праці, питання інвестиційної діяльності на рівні регіону потребують більш детального дослідження та наукового пошуку задля розв'язання наявних проблем. Передусім це виявляється в розробленні концептуальних засад формування механізмів залучення прямих іноземних інвестицій на підприємства регіону й рекомендацій щодо формування моделі інноваційного розвитку Чорноморського регіону. 


\section{МЕТА ДОСЛІДЖЕННЯ}

Головна мета дослідження - дослідження механізмів залучення прямих іноземних інвестицій на окремі підприємства Причорноморського регіону.

\section{МЕТОДИ, ОБ'ЄКТ ТА ПРЕДМЕТ ДОСЛІДЖЕННЯ}

Для досягнення мети в роботі використано загальні та спеціальні методи дослідження: аналіз і синтез - для вивчення основних форм і механізмів залучення прямих іноземних інвестицій; порівняльно-географічний метод систематизації - розглядається географічна структура; регіональні - аналізуються проблеми залучення прямих іноземних інвестицій на підприємства Чорноморського регіону; статистичний - надає статистику щодо розвитку прямих іноземних інвестицій в Україні.

\section{ОСНОВНИЙ МАТЕРІАЛ}

У сучасних умовах процес міжнародного руху капіталів тісно пов'язаний із розповсюдженням досягнень у галузі НДДКР, технології та менеджменту. Для країни вкладення капіталу пряме іноземне інвестування фактично становить джерело капітальних вкладень у виробництво товарів і послуг, а також імпорт робочих місць, технології, «ноу-хау», передових методів управління та маркетингу; подеколи завдяки виробничій і науково-технічній кооперації воно забезпечує ефективну інтеграцію національної економіки до світової, сприяє створенню конкурентного середовища.

За рахунок прямого іноземного інвестування приймаюча країна може запроваджувати нові технології й методи управління. Навіть за незначного обсягу вони сприяють поширенню інновацій, стимулюванню імітації та запозиченню найкращої ділової практики розвинених країн і збільшенню продуктивності праці.
На економіку приймаючої країни іноземне інвестування чинить двоякий вплив. 3 одного боку, через конкуренцію можливе гальмування розвитку або навіть банкрутство місцевих фірм. 3 іншого - навпаки, присутність іноземних філій змушує національні підприємства мобілізовувати зусилля до оптимізації виробничого потенціалу. У цьому зв'язку варто наголосити на суспільній корисності конкуренції, оскільки остання, безперечно, стимулює продуктивну працю, в т. ч. активізує інвестиційну та інноваційну діяльність, що в кінцевому підсумку зумовлює зниження витрат виробництва, покращення якості продукції та оновлення iii асортименту. Умови, що позбавляють фірми конкуренції, особливо світової, спричинюють неухильне зниження ефективності технологічного розвитку.

Розглянемо статистичні дані щодо розвитку прямого іноземного інвестування в Україні [3].

Таблиця 1. Динаміка прямих іноземних інвестицій в економіку України в 2010-2018 рр., млн. дол. США

\begin{tabular}{|c|c|c|}
\hline $\begin{array}{c}\text { Станом } \\
\text { на 01.01 }\end{array}$ & $\begin{array}{c}\text { Прямі інвестиції } \\
\text { в Україну }\end{array}$ & $\begin{array}{c}\text { Прямі інвестиції } \\
\text { з України }\end{array}$ \\
\hline $\mathbf{2 0 1 0}$ & 38992,9 & 5760,5 \\
\hline $\mathbf{2 0 1 1}$ & 45370,0 & 6402,8 \\
\hline $\mathbf{2 0 1 2}$ & 48197,6 & 6435,4 \\
\hline $\mathbf{2 0 1 3}$ & 51705,3 & 6568,1 \\
\hline $\mathbf{2 0 1 4}$ & 53704,0 & 6702,9 \\
\hline $\mathbf{2 0 1 5}$ & 38356,8 & 6456,2 \\
\hline $\mathbf{2 0 1 6}$ & 32122,5 & 6315,2 \\
\hline $\mathbf{2 0 1 7}$ & 31230,3 & 6346,3 \\
\hline $\mathbf{2 0 1 8}$ & 31606,4 & 6322,0 \\
\hline $\mathbf{3 1 . 1 2 . 2 0 1 8}$ & 32291,9 & 6295,0 \\
\hline
\end{tabular}

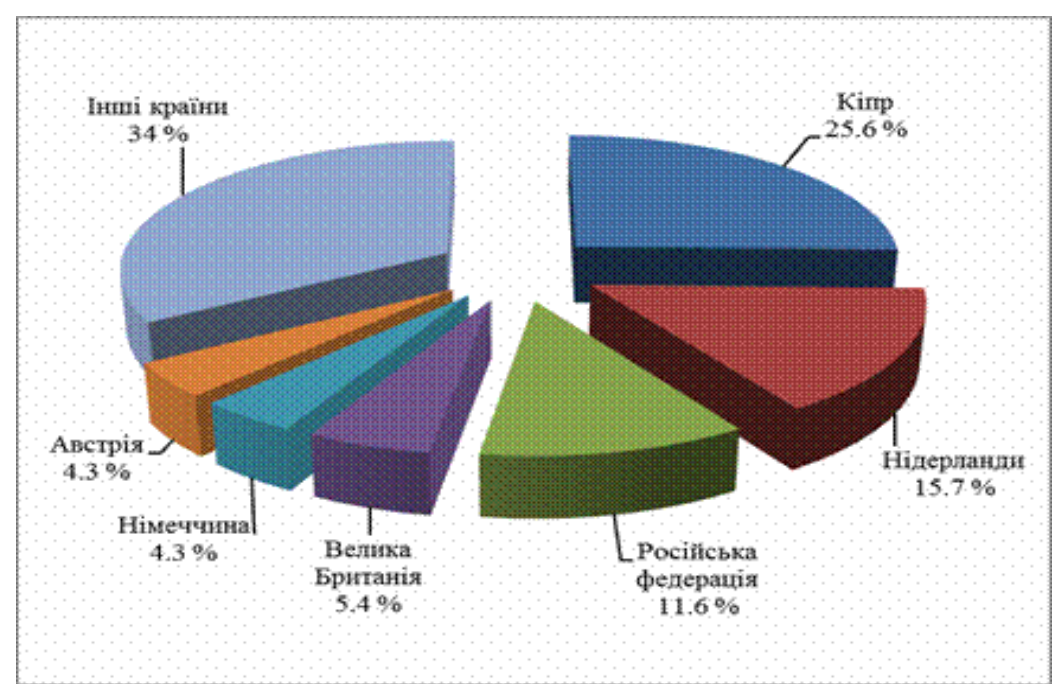

Рис. 1. Структура прямих іноземних інвестицій в економіці України за країнами світу станом на 01.01.2017 


\section{ЕКОНОМІКА ТА МЕНЕДЖМЕНТ № 1 2019}

32010 до 2018 року загальна сума прямих іноземних інвестицій в економіку України зменшилась iз 38992,9 до 32291,9 млн. дол. США. Пік прямих іноземних інвестицій припав на 2014 рік - 53704 млн. дол. США. Далі обсяг прямих іноземних інвестицій різко зменшився у 2015 році до 38356,8 млн. дол. США, показник продовжував зменшуватися й досяг мінімуму у 2017 році - 31230,3 млн. дол. США. А ось минулого року обсяг прямих іноземних інвестицій дещо зріс до 32291,9 млн. дол. США.

Надалі, характеризуючи пряме іноземне інвестування економіки України, розглянемо географічну структуру, що формується під впливом багатьох чинників, головним серед яких $\epsilon$ розвиток зовнішньоекономічних зв'язків зі стратегічними партнерами. Так, раніше основним партнером були США та Російська Федерація, у сучасних же умовах станом на 01.01.2017 головним стратегічним економічним партнером України є ЄС (рис. 1).

Отже, в останні 5 років існує схильність інвесторів до фінансових зловживань і відмивання коштів. Високий ступінь інвестування 3 такої країни, як Нiдерланди, пояснюється суттєвими пільгами для зареєстрованих у них іноземних компаній, а отже, їм притаманні певні елементи офшорності, проте незіставні з Кіпром. Режим офшорної зони, що діє на Кіпрі, сприяв здійсненню з території острова «опосередкованих» прямих іноземних інвестицій, які значно перевищують власні кіпрські інвестиції. Так, зазначимо, що значну частину прямих іноземних інвестицій 3 Кіпру здійснюють дочірні структури українських підприємств у фінансову та страхову сфери й торгівлю.

Інвестиційний процес в України гальмується низкою суб'єктивних та об'єктивних факторів, серед яких - політична й економічна нестабільність, часті зміни законодавства, повільні темпи приватизації, нерозв’язаність питань земельної власності тощо.

Особливою формою міжнародного економічного співробітництва $є$ концесія, яка також може розглядатися як механізм залучення іноземних інвестицій. Концесія являє собою договір на здачу в експлуатацію на визначених умовах землі, природних ресурсів, підприємств та інших господарських об'єктів, що належать державі. Концесійні договори укладаються на тривалі терміни, що є особливо сприятливим 3 погляду розвитку виробничого сектора економіки країни. Плата за користування концесією розраховується у вигляді відсотка на капітал, що вкладається в майно його власників, а також ренти. Конкретний розмір платні визначається в ході переговорів сторін, виходячи з міжнародної практики концесійного співробітництва та використовуваних ставок [1].

На території вільних економічних зон (далі - ВЕ3) запроваджуються пільгові митні, валютно-фінансові, податкові й інші умови економічної діяльності національних та іноземних юридичних і фізичних осіб.
Метою створення ВЕЗ є залучення іноземних інвестицій і сприяння їм, активізація спільно з іноземними інвесторами підприємницької діяльності для нарощування експорту товарів і послуг, поставок на внутрішній ринок високоякісної продукції та послуг, залучення й упровадження нових технологій, ринкових методів господарювання, розвиток інфраструктури ринку, поліпшення використання природних і трудових ресурсів, прискорення соціально-економічного розвитку України.

Створення ВЕ3, вільних міст та інших подібних районів стало одним із основних механізмів залучення іноземного капіталу в більшості країн світу.

Одним із важливих механізмів залучення прямих іноземних інвестицій є відкриття підприємств - філій транснаціональних компаній.

Транснаціональні корпорації (далі - ТНК), на думку експертів ООН, є «двигунами світової економіки». Саме так названа одна 3 доповідей по транснаціональних корпораціях. Натепер ТНК є такими ж рівноправними суб'єктами міжнародних економічних відносин, як і власне держави, а деякі найбільші ТНК навіть значно сильніші в економічному плані, ніж декілька держав світу. Добробут країни, її участь у міжнародному поділі праці, ступінь інтегрованості у світове господарство та ііі міжнародна конкурентоздатність більшою мірою залежать від того, наскільки успішна діяльність ТНК, що базуються на їі теритоpiï. Це досягається за рахунок того, що, з одного боку, за кордоном створюються нові ринки, а з іншого боку, частина експорту ТНК припадає на їх закордонні філії. Інвестиції, розміщені в межах території іноземної держави, дають змогу національній фірмі обійти тарифні й нетарифні бар'єри. Отже, для материнської країни відкривається доступ до нових ємких ринків, які колись були для неї недоступними[2].

Усі перераховані вище механізми залучення іноземних інвестицій можуть активно використовуватися в практиці. Проте особлива увага уряду повинна спрямовуватися на визначення пріоритетності застосування тих механізмів, що найбільшою мірою сприятимуть розвитку галузей і регіонів, які потребують значних надходжень і визначають розвиток економіки загалом.

Головними перепонами, які перешкоджають широкомасштабному залученню іноземних інвестицій для розвитку підприємств району, є:

- нестабільність законодавства в Україні, великий податковий тиск, неготовність більшості українських партнерів дотримуватися договірних зобов'язань;

- відсутність у підприємств розроблених інвестиційних проектів, які відповідали б міжнародним стандартам;

- $\quad$ поганий інвестиційний імідж країни загалом i невисокий рівень капіталізації прибутку підприємств; 
- $\quad$ недостатній рівень правового та судового захисту прав іноземних інвесторів і відсутність механізму страхування інвестиційного ризику [5].

\section{ОБГОВОРЕННЯ ОТРИМАНИХ РЕЗУЛЬТАТІВ}

Основні результати роботи обговорено на наукових конференціях професорсько-викладацького складу Миколаївського міжрегіонального інституту розвитку людини вищого навчального закладу «Відкритий міжнародний університет розвитку людини «Україна», Миколаїв, Україна.

\section{ВИСНОВКИ}

Підбиваючи підсумки проведеного дослідження особливостей залучення інвестицій в економіку України, варто наголосити на таких його головних результатах:
1. Іноземні інвестиції варто розглядати як будьякий вид майнових цінностей, вкладених іноземними інвесторами в іншу країну, враховуючи рухоме та нерухоме майно й пов'язані 3 ним майнові права, в т. ч. право під заклад: акції, облігації, різноманітні форми участі в компаніях; права вимоги на грошові засоби та послуги, які мають економічну цінність; права промислової та інтелектуальної власності тощо.

2. Обсяг іноземних інвестицій в економіку України є вкрай низьким і за останній рік можна спостерігати зниження інвестиційної активності, незважаючи на те що потреба української економіки в інвестиційних ресурсах становить не менше ніж 60 млрд. доларів США. Державна політика щодо іноземних інвестицій є недосконалою й потребує змін.

\section{REFERENCES}

[1] Byrka M.I. (2012) Sutnisna kharakterystyka pryamykh inozemnykh investytsiy [Intrinsic characteristics of foreign direct investment]. Bulletin of the National University «Lviv Polytechnic». Management and International Entrepreneurship in Ukraine: Stages of Formation and Development Problems. vol.727. pp. 301-308.

[2] Byrka M.I. (2014) Vrakhuvannya suchasnykh svitovykh i rehional'nykh tendentsiy pryamoho inozemnoho investuvannya $\mathrm{v}$ protsesi zaluchennya inozemnoho kapitalu na pidpryyemstva Ukrayiny [Taking into account current world and regional tendencies of foreign direct investment in the process of attracting foreign capital to Ukrainian enterprises]. Investment: practice and experience. no.10. pp. 56-61.

[3] Derzhavna sluzhby statystyky Ukrajiny. [State Statistics Service of Ukraine] Available at: http://www.ukrstat.gov.ua (accessed 25 September 2019).

[4] Ihnatenko M.V. (2016) Osoblyvosti protsesu zaluchennya inozemnykh investytsiy v ekonomiku Ukrayiny [Features of the process of attracting foreign investments in the economy of Ukraine]. University Economic Bulletin. no. 29. pp. 57-65.

[5] Skupsky R.M., Zubkov R.S. (2017) Monitoryngh reghionaljnykh problem rozvytku investycijno-innovacijnykh procesiv [Monitoring of regional problems of development of investment and innovation processes] KhNAU Bulletin. Collection of scientific works. Vol. 4. pp.461-472.

\section{СПИСОК ВИКОРИСТАНОЇ ЛІТЕРАТУРИ}

[1] Бирка M.I. Врахування сучасних світових і регіональних тенденцій прямого іноземного інвестування в процесі залучення іноземного капіталу на підприємства України. Інвестицї: практика та досвід. 2014. № 10. С. 56-61.

[2] Бирка М.І. Сутнісна характеристика прямих іноземних інвестицій. Вісник Національного університету «Львівська політехніка». Серія «Менеджмент та міжнародне підприємництво в Україні: етапи становлення і проблеми розвитку». 2012. № 727. С. 301-308.

[3] Державна служба статистики України: статистична інформація. URL: http://www.ukrstat.gov.ua (дата звернення: 25.09.2019).

[4] Ігнатенко М.В. Особливості процесу залучення іноземних інвестицій в економіку України. Економічний вісник університету. 2016. Вип. 29 (1). С. 57-65.

[5] Скупський Р.М., Зубков Р.С. Моніторинг регіональних проблем розвитку інвестиційно-інноваційних процесів. Вісник ХНАУ : збірник наукових праць. 2017. Вип. 4. С. 461-472. 